\title{
Sacral Tuberosity
}

National Cancer Institute

\section{Source}

National Cancer Institute. Sacral Tuberosity. NCI Thesaurus. Code C105447.

The prominence on the lateral surface of the sacrum, posterior to the auricular surface of the sacrum. 